\author{
Ryantika Dyah Safitri ${ }^{1}$ \\ Lilia Indriani ${ }^{2}$
}

\section{METACOGNITIVE STRATEGIES: INVESTIGATING EFL STUDENTS' SELF- EVALUATION OF SPEAKING PERFORMANCE DURING ONLINE LEARNING}

\begin{abstract}
Abstrak
Studi ini menginvestigasi evaluasi diri siswa EFL dalam kinerja berbicara untuk mengetahui strategi metakognitif yang digunakan selama kelas daring. Peserta merupakan 35 siswa EFL jurusan Bahasa Inggris di salah satu universitas negeri. Evaluasi diri adalah salah satu jenis strategi metakognitif dimana siswa menilai dan mengukur pekerjaan mereka (Amanda Arp, 2016). Penelitian ini didasarkan pada penelitian sebelumnya mengenai evaluasi diri oleh Amanda Arp tahun 2016. Peneliti menggunakan pengkodean evaluasi diri yang diadaptasi dari tiga puluh evaluasi diri berdasarkan penggunaan koding deskriptif (Saldaña). Kuesioner diberikan kepada siswa EFL untuk mengeksplorasi strategi evaluasi diri mereka terhadap kinerja berbicara mereka selama kelas daring. Hasil penelitian menunjukkan bahwa hampir semua peserta menerapkan strategi Metakognitif yaitu evaluasi diri terhadap penampilan berbicara mereka selama kelas online.
\end{abstract}

Kata Kunci: Evaluasi Diri, Kinerja Berbicara

\begin{abstract}
This study examines an investigation toward EFL students' self-evaluation in speaking performance to report the metacognitive strategies using during an online class. The participants were 35 EFL students at the English Department of a state university. Self-evaluation is a type of metacognitive strategy in which students assess and measure their work (Amanda Arp, 2016). This study is based on previous research regarding self-evaluation by Amanda Arp in 2016. Researcher using the coding self-evaluation that was adapted from thirty self-evaluations based on the use of descriptive coding (Saldaña). A questionnaire was administered to the EFL students to explore their self-evaluation strategy towards their speaking performance during online classes. The results show that there are almost all participants applied the Metacognitive strategy which is self-evaluation toward their speaking performance during an online class.
\end{abstract}

Keywords: Self-Evaluation, Speaking Performance.

\footnotetext{
${ }^{1}$ Pendidikan Bahasa Inggris, FKIP, Universitas Tidar email : Ryantika.ryn12@gmail.com

${ }^{2}$ Pendidikan Bahasa Inggris, FKIP, Universitas Tidar email : indriani@untidar.ac.id
} 


\section{INTRODUCTION}

Being able to apply the knowledge that has been learned is an imperceptible urgency. In the case of EFL, it is important for students to learn and master four basic skills namely speaking, listening, reading, and writing. Speaking is a skill that requires a lot of effort to master because various factors can affect the success rate of speaking skills. Speaking performance is a kind of skill that crucially applied in EFL class, it is being an important skill that students of higher level should master; it is related with the main competence applied in the society. Rather than just proficiency in grammar and semantics, speaking skills require more than just these things. (Ariyanti, 2016). Metacognitive strategies are important skills for students that must be developed (Anderson, 1991), active thinking, and skill to guide the development of learning performance (Anderson, 2003). According to O'Malley \& Chamot (1990: 44), metacognitive strategies are closely related to the process, planning, monitoring of learning, and evaluating student learning outcomes. Based on that statement we know metacognition is related to the student's awareness in the learning process. The learner is the main role in developing teaching methodologies because their awareness level in learning will help the teacher in utilizing these strategies. Fatemeh Takallou (2011) state that metacognitive consist of planning, selfmonitoring, and self-evaluation.

Many researchers have researched the effect of metacognitive strategies on EFL student skill enhancement. However, the previous research conducted by Amanda Arp (2016) was focused on the relation between self-evaluations and metacognition. In this study, the researcher investigating student self-evaluations in their speaking performance. This investigation also focuses on student's performance during online learning causes the learning condition during the pandemic. Self-assessments fill in as a task through which understudies can self-assess and fundamentally think about their work (Amanda, 2016). It is a kind of learning strategies can apply by the student during an online class. As we know, during the study from home policy, students are required to learn semi-self-taught. This is where students' creativity determines the achievement of successful language learning. EFL students often encounter self-evaluation strategies either directly or indirectly. The limitation of direct interaction with lecturers and friends makes self-evaluation become a dominant way for students to correct their learning progress. Discuss speaking performance, the student often feels how better they are or how worst they are in showing their speaking ability towards online conference method. The final objective of this research is an investigation towards the Metacognitive strategy using by EFL students of higher level during online class, in which the focus study is on the self-evaluation of EFL student in speaking performance.

\section{METHODOLOGY}

The writer completed the investigation using the coding self-evaluation conducted by Amanda Arp (2016). The coding was adapted from thirty self-evaluations based on the use of descriptive coding (Saldaña). The following is a description of the research procedures that researchers used in this study.

\section{Participant}

The participant of this research is EFL students of English Department at a state university. This research adopts a random sampling method to distribute the questionnaire. There are thirty-five EFL student participate to complete the questionnaire online. The participants are student undergraduates from the third and fifth semesters at Tidar University. The thirty-five participants will represent the EFL student within the basic speaking classes.

\section{Questionnaire}

Data collection was done using questionnaires given online to the EFL student randomly. The questionnaire was adapted from previous research by Amanda Arp (2016) in the form of a self-evaluation assessment created by LeFebvre. The questionnaire was readjusted to the 
author's needs, including the online class variable as a specification aspect in collecting data from the participant. Following are the questions that should fulfill by the participant:

1. What was the best thing(s) you feel during the online speaking performance?

2. What do you would like to change or do differently during the online speaking performance?

3. How would you intend to adjust your objectives to be more viable as a speaker for the following discourse? (Portray how you intend to change your methodology or systems for speechmaking to improve the adequacy and nature of your discourse)

4. How you describe your satisfaction with your speaking performance by video conference?

5. Did you notice the change in your speaking skills during the video conference? (Yes/No/Maybe)

6. Describe a change in how you perceived your speaking performance!

7. How many scores do you give on your speaking skills?

The first five questions were used to analyze metacognition based on descriptive coding. The rest consists of three questions that are not specifically related to metacognition. Its role as a support in the self-awareness assessment.

\section{Analysis}

The seven markers are a category for reading the results of students' discussions regarding metacognitive abilities. The analysis element is a long sentence that is broken down and elaborated according to the needs of category analysis. According to the previous study by Amanda Arp (2016), the writer compiles the results of the student descriptions into seven categories, namely; (1) a goal, (2) a part of their perspective process, (3) an expression of emotional contentment, (4) an expression of emotional discontent, (5) personal knowledge, (6) a change in perspective, and ( 7) other mental processes. Researchers investigated the results of grouping the seven markers.

\section{FINDINGS AND DISCUSSION}

A sampling of 32 EFL students by completing a questionnaire was conducted. The results of the descriptive coding analysis of the participants resulted in 7 categories called metacognitive markers in the self-evaluation aspect. The following are cognitive markers based on descriptive measurement data collection. The following are cognitive markers based on descriptive measurement data collection.

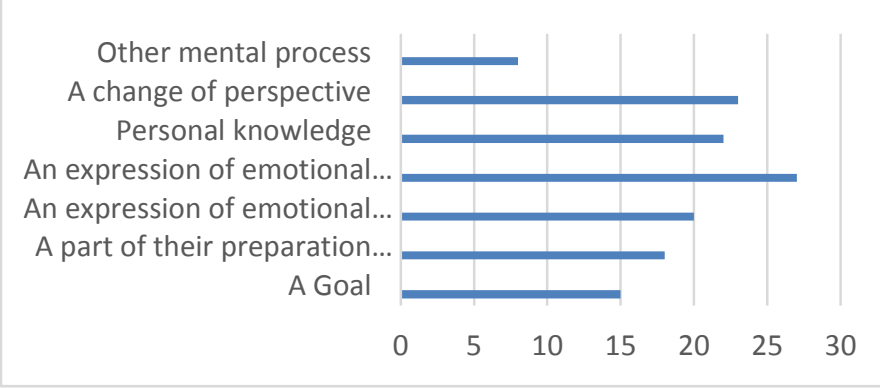

Figure 1. Number of students who expressed these Metacognitive markers

The results of students' metacognitive analysis in the self-evaluation aspect showed how the students thought in evaluating the results of speaking performance during an online class. These 7 metacognitive markers are categories of student achievement in metacognitive awareness that focus on students' ability to evaluate themselves on their performance.

1. A goal represents the awareness of students in making goals that will be achieved in the next performance. There are two examples of students' answers that represent the ability to make goals; "I can deliver my opinion properly" and "Deliver my thoughts without stuttering or using too much filler". There were fifteen students out of thirty-five who 
showed this type of metacognition. This is the second-lowest number among the seven markers.

2. Preparation represents the student's ability to arrange preparations before speaking performance during an online class. It is an example of students' answers that represents the student's setting preparations; "I would like to learn a significant English accent". Preparation of learning strategies to achieve satisfaction in the next performance. Among thirty-five students, there are eighteen who displayed this metacognitive marker. Become the third-lowest among the seven markers.

3. Emotional contentment represents student satisfaction after doing the online speaking performance. The student delivers their emotion such as proud, happy, interesting, and so on. Eleven students expressed happiness, two students felt proud and seven students felt their self-confidence grew. A total of twenty students expressed their emotional contentment among the thirty-five participants.

4. An expression of emotional discontent represents the opposite feeling of contentment towards their performance. Describing discontent such as nervousness, disappointment, confusion, etc. There are twenty-seven students expressed their discontent with; sixteen student feels nervous, four students expressed disappointment, five student fells confuse, the rest are angry and mad. In this case, Students might feel different emotions at the same time, in other words, they are sometimes satisfied with the results of their speaking performance, but sometimes they also feel that there are still shortcomings.

5. Personal knowledge, represents their experience in reviewing speaking performance, it can be a memory or a habit - "I become more confident". Students see the changes that occur during the online class by comparing their previous performances. Twentytwo student includes this cognition marker.

6. A change in perspective represents a change in performance by students in the form of a significant change in speaking performance in learning — "After watching myself deliver a speech, I will continue to practice to practice and develop my speaking skill and I will try to be more relax but serious during the presentation (speaking)". Similarly, as with different instances of this marker, this understudy portrayed an adjustment in their reasoning that came from the experience of re-watching and assessing their discourse. A total of twenty-three students exhibited this metacognition.

7. Other mental processes, represent other aspects of metacognition such as failing to remember, ability in understanding, or reminding — "After I finish doing the speaking activity, sometimes some of what I have learned and want to convey is that I have forgotten, so bringing a note of the material keywords that I will convey will help me". Among the thirty-five students, only eight exhibited this metacognition, to be the lowest number among other markers.

Students' metacognition analysis in the self-evaluation aspect aims to explore metacognitive thinking about speaking performance during online learning. The seven markers help in showing metacognition illustrations in speaking performance which is one of the basic activities of language learning. Unlike previous studies that compared the application of the study markers or category to the portfolios described by Bokser et al, the comparison of this analysis with previous research by Amanda Arp (2016) lies in a category that is focused on online learning. The results of this study indicate variations in metacognition markers in the form of seven markers that are used or applied by students in their online speaking performance evaluation. The seven markers show the focus of research on the application of goals, emotional expressions, and learning perspectives.

This study revealed students' perspectives and learning strategies after self-evaluating their speaking performance. In the Personal knowledge marker, students describe evaluation by linking or comparing experiences during the learning process. Students tend to measure their abilities by comparing previous performance, to see if there are significant changes. "I become more confident" is an example of a student's statement that measures his current ability. In the 
markers of goal setting and change, students' perspectives describe the influence of their experiences on potential errors in the learning process, where this is used as motivation to set target goals. This is closely related to the marker preparation process as a strategy to achieve targets either through changes in learning methods or by improving the quality of the learning method itself.

In the expression of emotional and mental process markers, students tend to explain how the learning process is by discussing the preparations they evaluate. Besides, students also express satisfaction and dissatisfaction with the process and the results of their performance. Students tend to express their decisions regarding new experiences or successes they have achieved and show dissatisfaction with failures in their performance that actually cannot be considered complete failures. This is based on the importance of elements of the learning process which for some reason can override the results. The reason can be in the form of the development of the learning process shown by students in their performance. Thirty-five samples show that emotional responses can affect the quality of their speaking performance. Students are also able to compare changes based on offline and online learning experiences. Self-evaluation increases students' metacognitive awareness in language learning in the speaking class.

\section{CONCLUSION}

This study attempted to investigate the metacognitive abilities of EFL students in the selfevaluation genre. The author conducted research that focused on speaking class to explore students' responses in their speaking performance. Based on the results of the search for student descriptions in the seven markers; (1) a goal, (2) a part of their perspective process, (3) an expression of emotional contentment, (4) an expression of emotional discontent, (5) personal knowledge, (6) a change in perspective, and ( 7) other mental processes, it can be concluded that most students can demonstrate their ability to evaluate themselves, namely the ability to recognize abilities and develop strategies for achieving learning targets. Students need to be able to analyze their abilities because it is useful in helping increase student success in language learning by utilizing students' metacognitive awareness.

\section{REFERENCES}

Ahangari, S., Rassekh-Alqol, B., \& Hamed, L. A. A. (2013). The effect of peer assessment on oral presentation in an EFL context. International Journal of Applied Linguistics and English Literature, 2(3), 45-53. https://doi.org/10.7575/aiac.ijalel.v.2n.3p.45

Al-Alwan, A., Asassfeh, S., \& Al-Shboul, Y. (2013). EFL learners' listening comprehension and awareness of metacognitive strategies: How are they related. International Education Studies, 6(9), 31-39. https://doi.org/10.5539/ies.v6n9p31

Ariyanti, A. (2016). Psychological Factors Affecting EFL Students' Speaking Performance. ASIAN TEFL Journal of Language Teaching and Applied Linguistics, 1(1), 77-88. https://doi.org/10.21462/asiantefl.v1i1.14

Arp, A. (2016). Examining Student Metacognition when Self-Evaluating Public Speaking by.

Asakereh, A., \& Dehghannezhad, M. (2015). Student satisfaction with EFL speaking classes: Relating speaking self-efficacy and skills achievement. Issues in Educational Research, 25(4), 345-363.

Çağatay, S. (2015). Examining EFL Students' Foreign Language Speaking Anxiety: The Case at a Turkish State University. Procedia - Social and Behavioral Sciences, 199, 648-656. https://doi.org/10.1016/j.sbspro.2015.07.594

Djahimo, S. E. . (2018). Student anxiety and their speaking performance: teaching EFL to Indonesian student. International Journal of Social Sciences and Humanities, 2(3), 187195. https://doi.org/10.29332/ijssh.v2n3.235

Ellis, D., \& Zimmerman, B. J. (2001). Enhancing Self-Monitoring during Self-Regulated 
Learning of Speech. 205-228. https://doi.org/10.1007/978-94-017-2243-8_10

Fazeli, S. H. (2012). Use of the metacognitive English language learning strategies based on personality traits. Theory and Practice in Language Studies, 2(3), 531-539. https://doi.org/10.4304/tpls.2.3.531-539

Harrison, G. M., \& Vallin, L. M. (2018). Evaluating the metacognitive awareness inventory using empirical factor-structure evidence. Metacognition and Learning, 13(1), 15-38. https://doi.org/10.1007/s11409-017-9176-Z

Hosni, S. (2014). Speaking Difficulties Encountered by Young EFL Learners. International Journal on Studies in English Language and Literature, 2(6), 22-30.

Huisman, B., Saab, N., Van Driel, J., \& Van Den Broek, P. (2020). A questionnaire to assess students' beliefs about peer-feedback. Innovations in Education and Teaching International, 57(3), 328-338. https://doi.org/10.1080/14703297.2019.1630294

J. H. Flavell. (1979). Metacognition and cognitive monitoring: A new area of cognitivedevelopmental inquiry. American Psychologist, 34(10), 906-911.

Joo, S. H. (2016). Self- and Peer-Assessment of Speaking. Working Papers in TESOL and Applied Linguistics, 16(2), 68-83. http://dx.doi.org/10.7916/D8FN2D1S

Limongelli, C., Sciarrone, F., Temperini, M., \& Vaste, G. (2009). Adaptive learning with the LS-Plan system: A field evaluation. IEEE Transactions on Learning Technologies, 2(3), 203-215. https://doi.org/10.1109/TLT.2009.25

Meijer, J., Sleegers, P., Elshout-Mohr, M., van Daalen-Kapteijns, M., Meeus, W., \& Tempelaar, D. (2013). The development of a questionnaire on metacognition for students in higher education. Educational Research, 55(1), 31-52. https://doi.org/10.1080/00131881.2013.767024

Oxford. (1989). how well the statement describes YOU. English, 0.

OZTURK, N. (2017). Assessing Metacognition: Theory and Practices. International Journal of Assessment Tools in Education, March 2017, 134-134. https://doi.org/10.21449/ijate.298299

Prof. Ag. Bambang Setiyadi; Ph.D. (2016). LANGUAGE LEARNING STRATEGY QUESTIONNAIRE (LLSQ) A Measurement to Identify Students' Learning Strategies and Prepare the Success of Learning English in the Indonesian Context (Empirical Evidence). Graha Ilmu, 1-124.

Rahimi, M., \& Katal, M. (2012). Metacognitive strategies awareness and success in learning english as a foreign language: An overview. Procedia - Social and Behavioral Sciences, 31(2011), 73-81. https://doi.org/10.1016/j.sbspro.2011.12.019

Robertson, P., \& Nunn, R. (2011). How_English_L2_learners_in_China_perceive_and_inte. 13(1).

Savira, S. I., \& Laksmiwati, H. (2017). Self-Assessment to Assess Student's Performance in Academic Task to Improve Metacognition. 118, 80-86. https://doi.org/10.2991/icset17.2017.14

Schraw, G., \& Dennison, R. S. (1994). MAI Tabela 1 MB. Contemporary Educational Psychology, 19, 460-475. https://www.harford.edu/ /media/PDF/StudentServices/Tutoring/Metacognition Awareness Inventory.ashx

Setiyadi, A. B. (2001). Language Learning Strategies: Classification and Pedagogical Implication. TEFLIN Journal, 12(1), 15-28. https://doi.org/10.15639/teflinjournal.v12i1/15-28

Sevilla Morales, H., \& Gamboa Mena, R. (2017). Student Self-Evaluation and Autonomy Development in EFL Learning. Revista de Lenguas Modernas, 25, 199-222. https://doi.org/10.15517/rlm.v0i25.27695

Shannon, S. (2008). Using metacognitive strategies and learning styles to create self-directed learners. Institute for Learning Styles Journal, 1(2001), 14-28. http://www.auburn.edu/academic/education/ilsrj/Journal Volumes/Fall 2008 Volume 1 PDFs/Metacognitive Strategies and Learning Styles.pdf\%0Ahttp://www.auburn.edu/ witteje/ilsrj/Journal Volumes/Fall 2008 Volume 1 
PDFs/Metacognitive Strategies and Learning St

Ünver, M. M., Aydın, B., \& Eş, Ş. (2016). A Preliminary Study on Oral Performances of English learners in L1 and L2. Anadolu Journal Of Educational Sciences International, 6(2). https://doi.org/10.18039/ajesi.69829

$\mathrm{Xu}, \mathrm{W}$. (2012). A survey on metacognitive strategy use in college oral English study under internet environment-with a case study of Guilin University of Technology. Theory and Practice in Language Studies, 2(7), 1430-1435. https://doi.org/10.4304/tpls.2.7.1430-1435 